\title{
Editorial
}

\section{Infections: HIV and related-diseases, anti-microbial resistance and neglected tropical diseases}

\author{
David Mukunya
}

PhD Candidate, Centre for International Health, University of Bergen, Norway.

DOI: https://dx.doi.org/10.4314/ahs.v19i2.2

Cite as: Mukunya D. Infections: HIV and related-diseases, anti-microbial resistance and neglected tropical diseases. Afri Health Sci.2019;19(2): IV-V. https://dx.doi.org/10.4314/abs.v19i2.2

In this infectious disease section of the June issue of African Health Sciences, we begin with papers on 'the usual suspect' HIV; which contributes a significant portion of disability adjusted life years lost in low and middle-income countries. Howlett reviews HIV neurological disorders in Africa, and characterizes them based on their aetiology into: HIV infection, auto immune, and opportunistic process related disorders ${ }^{1}$. Nigerian authors report on adrenocortical deficiency ${ }^{2}$ and Hepatitis B virus ${ }^{3}$, among HIV patients. Viruses have unexpected effects, which are often ignored by clinicians. Bal et al report on reduced pulmonary function among participants with high Hepatitis $C$ viremia ${ }^{4}$. Ugandan authors classify and describe chronic pain among HIV patients. They report that $1 / 5^{\text {th }}$ of all HIV patients had chronic pain and this was associated with poor quality of life ${ }^{5}$.

From HIV and related diseases, we turn to anti-microbial resistance:

Anti-microbial resistance is a growing threat world wide, and in this issue, we offer some insight into the subject in the Africa context. Tunisian authors report high prevalence of Extended Spectrum Beta-Lactamase (ESBL) producing bacteria ${ }^{6}$ and on carbapenem resistance mechanisms in Klebsiella Pneumoniae isolates ${ }^{7}$. Crossing over to gram-positive bacteria, Nigerian authors ${ }^{8}$ report on the phenotypes of methicillin resistant Staphylococcus aureus. Out of Africa, Chinese authors report on multidrug resistant bacteria among patients re-admitted with acute exacerbations of chronic obstructive pulmonary disease (COPD). They found that the commonest potentially pathogenic organism isolated from patients with acute exacerbation of COPD as Pseudomonas aeroginosa'. Saleh et al give us insight into how we can tackle Pseudomonas aeruginos $a^{10}$. Ugandan authors report that $9 \%$ of culture confirmed TB patients developed recurrent TB, and they determined predictors of recurrence ${ }^{11}$.

Neglected tropical diseases:

Nigerian authors report that Dengue is a growing public health problem in their country ${ }^{12}$, and that levels of stigma against Buruli ulcer disease are high ${ }^{13}$. On the surgical front, Salako et al report that $10 \%$ of patients who underwent prostatectomy in a Nigerian Teaching Hospital suffered from a surgical site infection ${ }^{14}$, while Omorogiuwa et al report that Cymbopogoncitratus Stapf leaf is a potential treatment of male reproductive related infections ${ }^{15}$.

Gastrointestinal infections are a major cause of morbidity and mortality in under- 5 year olds. One of the greatest public health advances in the last century was the development of vaccines. However the failure to maintain a cold chain renders the efficacy of most vaccines uncertain. Osaretin et al report that a monovalent rotavirus vaccine remained potent after exposure to different temperatures in South Africa ${ }^{16}$, which is good news. Subbaram et al recommend immune magnetic polymerase chain reaction for the molecular identification of diarrheal Aeromonas from clinical specimens ${ }^{17}$. Babatola et al report that one third of asymptomatic under-five children at a tertiary hospital in South West Nigeria had anti H.Pylori Ig G in their blood; and they determine the risk factors for this sero-positivity ${ }^{18}$, this is scary news given that $H$. Pylori is a group 1 carcinogen.

Enjoy the section!

\section{References}

1. Howlett WP. Neurological disorders in HIV in Africa: a review. Afri Health Sci. 2019;19(2). 1953-1977. https:/ / dx.doi.org/10.4314/ahs.v19i2.19

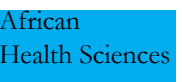

(C) 2019 Mukunya D. Licensee African Health Sciences. This is an Open Access article distributed under the terms of the Creative commons Attribution License (https://creativecommons.org/licenses/BY/4.0), which permits unrestricted use, distribution, and reproduction in any medium, provided the original work is properly cited.

African Health Sciences Vol 19 Issue 2, June, 2019 
2. Akase IE, Habib AG, Bakari AG, Muhammad H, Gezawa ID. The prevalence and clinical profile of adrenocortical deficiency among HIV infected persons in Northern Nigeria. Afri Health Sci. 2019;19(2). 1947-1952. https:// dx.doi.org/10.4314/ahs.v19i2.19

3. Omatola CA, Idofe J, Okolo M-LO, Adejo PO, Maina MM, Oyiguh JA. Seroprevalence of HBV among people living with HIV in Anyigba, Kogi State, Nigeria. Afri Health Sci. 2019;19(2). 1938-1946. https://dx.doi. org/10.4314/ahs.v19i2.17

4. Bal Tayibe et al. The impact of hepatitis $C$ viremia status on lung functions in chronichepatitis c patients. Afri Health Sci. 2019;19(2). 1988-1992. https://dx.doi. org/10.4314/ahs.v19i2.21

5. Mwesiga EK, Kaddumukasa M, Mugenyi L, Nakasujja N. Classification and description of chronic pain among HIV positive patients in Uganda. Afri Health Sci. 2019;19(2). 1978-1987. https://dx.doi.org/10.4314/ahs. v19i2.20

6. Mechergui A, Achour W, Mathlouthi S, Hassen AB. Prevalence of infectious multi-drug resistant bacteria isolated from immuno compromised patients in Tunisia. Afri Health Sci. 2019;19(2). 2021-2025. https://dx.doi. org/10.4314/ahs.v19i2.25

7. Messaoudi A, Mansour W, Jaidane N, Chaouch C, Boujaâfar N, Bouallègue O. Epidemiology of resistance and phenotypic characterization of carbapenem resistance mechanisms in Klebsiella pneumoniae isolates at Sahloul University Hospital-Sousse, Tunisia. Afri Health Sci. 2019;19(2). 2008-2020. https://dx.doi.org/10.4314/ ahs.v19i2.24

8. Ariom TO, Iroha IR, Moses IB, Iroha CS, Ude UI, Kalu AC. Detection and phenotypic characterization of methicillin-resistant staphylococcus aureus from clinical and community samples in abakaliki, Ebonyi State, Nigeria. Afri Health Sci. 2019;19(2). 2026-2035. https:/ /dx.doi. org/10.4314/ahs.v19i2.26

9. Lin J, He S-S, Xu Y-Z, Li H-Y, Wu X-M, Feng J-X. Bacterial etiology in early re-admission patients with acute exacerbation of chronic obstructive pulmonary disease. Afri Health Sci. 2019;19(2). 2073-2081. https://dx.doi. org/10.4314/ahs.v19i2.31

10. Saleh MM, Sadeq RA, Abdel Latif HK, Abbas HA, Askoura M. Zinc oxide nanoparticles inhibits quorum sensing and virulence in Pseudomonas aeruginosa.
Afri Health Sci. 2019;19(2). 2043-2055. https://dx.doi. org/10.4314/ahs.v19i2.28

11. Muzanyi G, Mulumba Y, Mubiri P, Mayanja H, Johnson JL, Mupere E. Predictors of recurrent TB in sputum smear and culture positive adults: a prospective cohort study. Afri Health Sci. 2019;19(2). 2091-2099. https://dx. doi.org/10.4314/ahs.v19i2.33

12. Otu A, Ebenso B, Etokidem A, Chukwuekezie O. Dengue fever - an update review and implications for Nigeria, and similar countries. Afri Health Sci. 2019;19(2). 2000-2007. https://dx.doi.org/10.4314/ahs.v19i2.23

13. Nwafor CC, Meka A, Chukwu JN, Ekeke N, Alphonsus C, Mbah O, Madichie NO, Aduh U, Ogbeifo M, IseOluwa-Adelokiki BO, Edochie JE, Ushaka J, Ukwaja KN. Assessment of community knowledge, attitude, and stigma of Buruli ulcer disease in Southern Nigeria. Afri Health Sci. 2019;19(2). 2100-2111. https://dx.doi. org/10.4314/ahs.v19i2.34

14. Salako AA, Badmus TA, Onyia CU, Rotimi AD, Adejare IE, Lawal AO, Onyeze CI, Ndegbu CU. An audit of surgical site infection following open prostatectomy in a Nigerian Teaching Hospital. Afri Health Sci. 2019;19(2). 2068-2072. https://dx.doi.org/10.4314/ahs.v19i2.30 15. Erhabor JO, Erhabor RC, ldu M-D. In vitro antibacterial and cytogenotoxicological properties of the aqueous extract of Cymbopogoncitratus Stapf (DC) leaf. Afri Health Sci. 2019;19(2). 2056-2067. https://dx.doi. org/10.4314/ahs.v19i2.29

16. Asowata OE, Ashiru OT, Sturm AW, Moodley P. Stability of a monovalent rotavirus vaccine after exposure to different temperatures observed in KwaZulu-Natal, South Africa. Afri Health Sci. 2019;19(2). 1993-1999. https://dx.doi.org/10.4314/ahs.v19i2.22

17. Subbaram K, Gatasheh MK, Al Azzam KM, Kannan H. Molecular identification of diarrheal Aeromonasusing immuno magnetic polymerase chain reaction (IM-PCR) technique: a comparative study with conventional culture method. Afri Health Sci. 2019;19(2). 2036-2042. https:// dx.doi.org/10.4314/ahs.v19i2.27

18. Babatola AO, Akinbami FO, Adeodu OO, Ojo TO, Efere MO, Olatunya OS. Seroprevalence and determinants of Helicobacter pylori infection among asymptomatic under-five children at a Tertiary Hospital in the South-Western region of Nigeria. Afri Health Sci. 2019;19(2). 20822090. https://dx.doi.org/10.4314/ahs.v19i2.32 